\title{
Oxidation of indolic bases by cytochrome P450 and ferrous picolinate
}

\author{
K. Jankowski* \\ Faculté des Études Supérieures et de la Recherche, Université de Moncton, Moncton, N.-B., \\ E1A 3E9, Canada
}

M. Delaforge and M. Jaouen

Université René Descartes, URA 400 CNRS, 75270 Paris, France

H. Virelizier**

Faculté des Études Supérieures et de la Recherche, Université de Moncton, Moncton, N.-B., E1A 3E9, Canada

Received January 1995

Revised March 1996

Abstract. Oxidations performed on four indolic bases, $\beta$-carboline $\underline{1}$, ibogaine $\underline{2}$, reserpine $\underline{3}$ and ajmaline $\underline{4}$, by hepatic cytochrome P450 (Cyt. P450) and ferrous picolinate ( $\left.\mathrm{Fe}(\mathrm{PA})_{2}\right)$, lead to alicyclic hydroxylation as major reaction products.

\section{Introduction}

In the field of biomimetic or biological oxidation reactions, the enzyme cytochromes P450, Cyt. P450, have an important place in specific oxydations of exogenous and endogenous substrates [15]. The cytochromes P450 exist in almost every living cell. They oxidize specific substrates, such as steroids, or whole families of substrates such as those containing aromatic hydrocarbons. They consist of high molecular weight proteins, ca. $47-52 \mathrm{kDa}$, are abundant in the liver, but can also be isolated from other sources [6]. They are fragile and the yields of oxidation, using Cyt. P450 oxidizing agent, are generally low, lower than a few percent, depending on the substrate used and the selectivity of the enzyme. The essential part of the Cyt. P450 oxidation system is a cysteine-heme cavity completely enveloped in a protein. The heme, from the chemical point of view is a $\mathrm{Fe}(\mathrm{II}) / \mathrm{Fe}$ (III) red-ox system and constitutes of an apolar site. The access to this site is limited, however several bulky, charged and voluminous molecules can reach it, become complexed and get oxidized. The cytochromes P450 have an important reactive selectivity - both regio- and stereoselectivities - that is characteristic of their active site, as in $11 \beta$ or 18 -hydroxylation of steroids by Cyt. P450. Several Cyt. P450 present larger

\footnotetext{
${ }^{*}$ To whom all inquiries should be addressed.

${ }^{* *}$ Permanent address: CEN Saclay, SAIS, bât. 391, B.P. 2, 91191 Gif-sur-Yvette, France.
} 
Table 1

$\mathrm{Fe}(\mathrm{PA})_{2}$ oxidation

\begin{tabular}{|c|c|c|c|c|c|c|c|}
\hline \multirow[t]{3}{*}{ Substrate } & \multirow{3}{*}{$\begin{array}{l}\text { Total yield } \\
\text { of } \\
\text { products }(\%)\end{array}$} & \multicolumn{6}{|c|}{ Product profiles (\%) } \\
\hline & & red & one & ol & dione & diol & Py-coup ${ }^{a}$ \\
\hline & & $\mathrm{M}+2$ & $\mathrm{M}+14$ & $M+16$ & $\mathrm{M}+28$ & $\mathrm{M}+32$ & $\mathrm{M}+78$ \\
\hline 1 & 7.6 & 13 & 12 & 50 & 7 & 14 & 12 \\
\hline $1-d_{2}-7,7$ & 7.8 & 6 & 3 & 65 & 10 & 15 & 15 \\
\hline$\overline{2}$ & 3.8 & 52 & 14 & 12 & 12 & 10 & 5 \\
\hline$\underline{3}$ & 0.1 & 15 & 6 & 60 & 1 & 18 & 1 \\
\hline$\underline{4}$ & 1.0 & 16 & 19 & 36 & 21 & 8 & 5 \\
\hline
\end{tabular}

channels toward substrates, e.g., P450A four metabolizing fatty acids. They can bind large molecules by substrate controlled thermally expandable openings, e.g., cyclosporine (molecular weight around $1,4 \mathrm{kDa})$, metabolized by isozyme $3 \mathrm{~A}$.

The trend to imitate and improve the Cyt. P450 oxidation consists of reducing their active site to a simpler $\mathrm{Fe}(\mathrm{II}) / \mathrm{Fe}$ (III)-catalyst system. In such manner, Professor Barton's Gif system family oxidation [7-11] has been developed as well as $\mathrm{Fe}(\mathrm{PA})_{2}$, ferrous picolinate, and other Sawyer reagents [12].

The oxidation with Cyt. P450 or methane monooxygenase (MMO) like systems usually leads to mono or, in some cases, polyhydroxy or carbonyl products formation. The oxidation of indolic compounds, simple bases or alkaloids, by various reagents, results in aromatic or aliphatic (alicyclic) hydroxylation, in carbonyl formation from the methylene group, different coupling reactions (such as substrate-solvent if present), in hydrolysis, and in competitive autooxidation by atmospheric oxygen. In particular, the indolic bases are very sensitive to oxidation. They easily undergo skeletal rearrangements, especially induced at $\mathrm{C}_{2}$ or $\mathrm{C}_{3}$ oxidized carbons. The dioxidation or epoxidation, occasionally reported for simple molecules and observed in Gif IV oxidation [13-15], barely takes place for simple indole bases. The indolic nitrogen, being in the enamine position, is oxidation sensitive, however, the epoxidation of the $\mathrm{C}_{2}-\mathrm{C}_{3}$ bond, the epoxide rearrangement and the 2,3-diol formation are difficult to achieve, though possible. The complex biological oxidation systems often display red-ox characteristics, i.e., the reduction and oxidation products are observed together [16,17]. In some cases, the methylated (e.g., methoxy) alkaloids undergo demethylation under the reaction conditions.

In this study, we present the oxidation of four indolic derivatives such as $\beta$-carboline ( 1 ), ibogaine $(\underline{2})$, reserpine ( $\underline{3}$ ) and ajmaline ( $\underline{4})$ (see Fig. 1), by rat liver Cyt. P450 and by $\mathrm{Fe}(\mathrm{PA})_{2}$, and compare them to Gif oxidation results for the same set of compounds (Table 1). Finally, the tentative explanation of the reactivity of the indolic bases towards oxidation systems is advanced.

\section{Experimental}

\subsection{Material and methods}

The carboline 1 and its deuterated carbolines were synthesized by ourselves [18,19] according to the modified Gribble procedure [20,21]. The bases $\underline{2}-\underline{4}$ were obtained from Aldrich Chemical Co. 


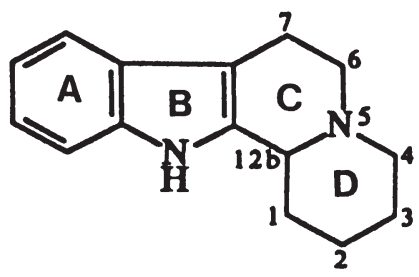

1

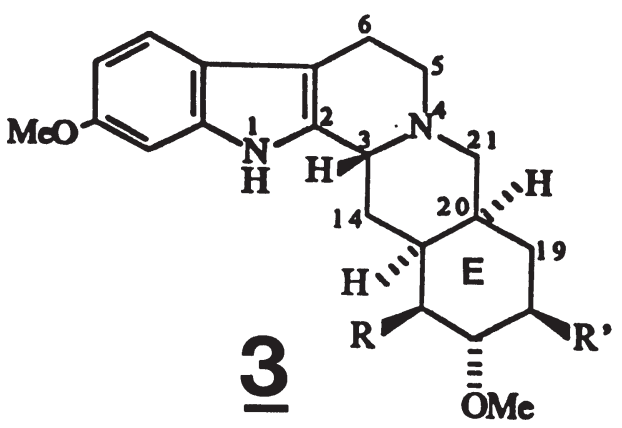

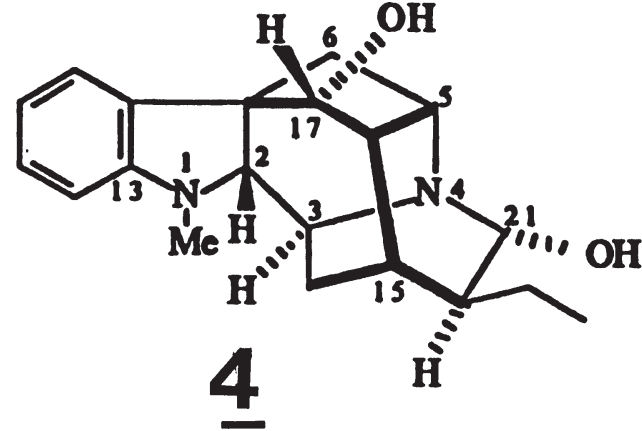

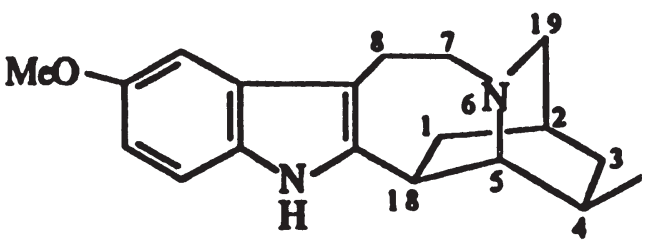

$\underline{2}$

\section{$R=$ COOMe; $\mathbf{R}^{\prime}=$ OCOTMP \\ (TMP $=3^{\prime}, 4^{\prime}, 5^{\prime}$ - trimethoxyphenyl )}

Fig. 1. Indole alkaloids $\underline{1}-\underline{4}$.

\subsection{Preparation of $\mathrm{Fe}(\mathrm{PA})_{2}$}

The preparation of $\mathrm{Fe}(\mathrm{PA})_{2}$ was done following a Sheu's two-step procedure [22,23]: i) tetramethylammonium picolinate obtained from the neutralisation of picolinic acid by tetramethylammonium hydroxide pentahydrate and ferrous perchlorate mixed together, and ii) the brick red cristals of $\mathrm{Fe}(\mathrm{PA})_{2}$ recristallised from acetonitrile $[24,25]$.

\subsection{Oxidation of substrates by Cyt. P450}

Preparation of active Cyt. P450. The hepatic microsomes of male rat either treated or untreated with a) phenobarbital (PB $0.1 \%$ in drinking water for five days), b) 3-methylcholanthrene (3-MC, $20 \mathrm{mg} / \mathrm{kg}$ daily in corn oil i.p. for three days), c) dexamethasone (DEX, $100 \mathrm{mg} / \mathrm{kg}$ daily in corn oil i.p. for three days) were used. (Two other inducing agents, clofibrate and $\beta$-naphtoflavone, lead to an induced P450 which was unable to react with the carboline 1.)

Microsomes were prepared according to the Kremers procedure [26] and the proteins, the cytochrome $\mathrm{b}_{5}$ and the Cyt. P450 levels were evaluated as already described [27,28]. The cytochrome P450 activities were evaluated using classical substrates of the various isoforms: ethoxyresorufin $\mathrm{N}$ deethylase for the 3-MC treated rat microsomes, benzphetamine N-demethylase for the PB treated rat microsomes and erythromycin N-demethylase for Dex treated rat microsomes [6]. 


\subsection{Oxidation}

The incubations were performed in phosphate buffer $(0.1 \mathrm{M}, \mathrm{pH} 7.4,0.1 \mathrm{mM}$ EDTA, $1 \mathrm{ml}$ final volume) with addition of a reduced Nicotinamide Dinucleotide Phosphate (NADPH) $0.5 \mathrm{mM}$ for 30 $\mathrm{min}$. or for $10 \mathrm{~min}$. in the presence of cumene hydroperoxide (CumOOH $0.5 \mathrm{mM}$ ). The reactions, initiated by addition of substrate, were stopped by addition of dichloromethane $(2 \mathrm{ml})$. The products were extracted, washed with water and the organic phase was carefully dried before MS analysis.

\subsection{Oxidation of substrates by $\mathrm{Fe}(P A)_{2}$}

This reaction was performed according to the Sawyer's procedure [12]. The substrate $(0.5-1.0 \mathrm{mM})$ and the catalyst $\left(20: 1 \mathrm{HOOH}: \mathrm{Fe}(\mathrm{PA})_{2}\right)$ were used, in pyridine acetic acid $(2: 1 \mathrm{M} / \mathrm{M}$ ratio $)$ mixture, the hydrogen peroxide being a limiting reagent. The mixture was stirred up at room temperature for four hours.

In both reactions, the work-up procedures consisted in preconcentration and solvent removal the same as in Gif reactions [29,30].

\subsection{GC-MS studies of reaction mixtures - identification of oxidation products}

The GC-MS studies were performed on Riber 1030 (Nermag) spectrometer (electron impact EI, positive ion PI, $70 \mathrm{eV}, 200^{\circ}$, capillary column CpSil $50 \mathrm{~m}, 0.4 \mu \mathrm{m}$ ). The monitoring and the quantitation of the oxidation products (mono and dihydroxylation as well as the carbonyl derivatives) were performed in the manner previously described $[29,30]$.

The mass chromatograms were run using $\mathrm{M}+2$ ion intensity for the reduction products, $\mathrm{M}+14$ ion for the keto/epoxy, M+16 ion for the hydroxy and M+32 ion for the diol. The findings were confirmed by the comparison with available standards $[13,18,19]$. The origin of $\mathrm{M}+2$ ion for the compounds $\underline{2}-\underline{4}$ can be explained by the sequence of demethylation of $\mathrm{OCH}_{3}$ or $\mathrm{NCH}_{3}$ groups, followed by monohydroxylation.

In order to evaluate the relative efficiencies of reaction, the cyclohexane oxidation by Cyt. P450, $\mathrm{Fe}(\mathrm{PA})_{2}$ or Gif IV was performed according to Ullrich [31,32], Sawyer [12] and Barton [4,5] procedures respectively. The results were corrected for the autooxidation of substrates by atmospheric oxygen by comparing the GC-MS mixtures obtained with those run under $\mathrm{N}_{2}$ atmosphere.

The identification of oxidation products was done using some available keto or hydroxy indolic bases which were obtained independently, e.g., by Gif oxidation or soft reduction of a corresponding lactame in previous studies $[13,29,30]$.

\subsection{Preliminary evaluation of dedeuteration under oxidation conditions}

Both deuterated isomers of carboline $\underline{1}, 4,4-d_{2}$ and 7,7- $d_{2}$, slowly exchanged their deuterium under Cyt. P450 $\mathrm{Fe}(\mathrm{PA})_{2}$ or Gif oxidative conditions. Two controls have been performed: first, the dedeuteration by the microsomes, coming from the treated or untreated animals with usual inducers $\mathrm{PB}, \mathrm{DEX}$ or 3-MC but without NADPH or $\mathrm{CumOOH}$ and second, the dedeuteration of carbolines in the presence of NADPH or $\mathrm{CumOOH}$ alone. Under Cyt. P450 oxidation conditions, the isomer $1-7,7-d_{2}$, with deuterium in benzylic, $\alpha$-to indole position, exchange faster than the isomer $4,4-d_{2}$ $\alpha$-to nitrogen $1-4,4-d_{2}$ isomer. For both isomers, a faster exchange was observed in the presence of $\mathrm{CumOOH}$ than for NADPH routes. 
Table 2

Comparison of reaction efficiencies ${ }^{\mathrm{a}}$

\begin{tabular}{|c|c|c|c|c|c|c|c|c|}
\hline \multirow[t]{3}{*}{ Substrate } & \multicolumn{8}{|c|}{ Oxidation agent (relative oxidation efficiency) } \\
\hline & \multirow[t]{2}{*}{ GIF IV } & \multirow[t]{2}{*}{$\mathrm{Fe}(\mathrm{PA})_{2}$} & \multicolumn{3}{|c|}{ Cyt. P450 (NADPH) } & \multicolumn{3}{|c|}{ Cyt. P450 (CumOOH) } \\
\hline & & & $\mathrm{b}$ & $\mathrm{c}$ & $\mathrm{d}$ & $\mathrm{b}$ & $\mathrm{c}$ & $\mathrm{d}$ \\
\hline 1 & 2.21 & 1.63 & 1.00 & 0.05 & 0.22 & 0.15 & 0.05 & 0.22 \\
\hline$\underline{2}$ & 1.30 & 0.84 & 0.37 & 0.04 & 0.11 & 0.03 & 0.29 & 0.06 \\
\hline$\underline{3}$ & 0.27 & 0.05 & 0.19 & 0.17 & 0.22 & 0.35 & 0.01 & 0.26 \\
\hline$\underline{\overline{4}}$ & 0.15 & 0.52 & 0.04 & 0.11 & 0.05 & 0.18 & 0.05 & 0.12 \\
\hline \multicolumn{9}{|c|}{$\begin{array}{l}\text { a In each column the relative efficiencies of reactions were reported as a specific total } \\
\text { ion current for organic ion current for all ox-ion mass chromatograms over the fraction. } \\
\text { The oxidation of carboline using PB-treated rat microsomes and NADPH route was } \\
\text { normalized as } 1.00 \text {. } \\
\text { b: PB - phenobarbital treated rat liver microsomes. } \\
\text { c: DEX - dexamethasone treated rat liver microsomes. } \\
\text { d: } 3-M C \text { - 3-methylcholanthrene treated rat liver microsomes. }\end{array}$} \\
\hline
\end{tabular}

The isomer $1-7,7-d_{2}$ displays $34.5 \%$ of dedeuteration after one day in pyridine and over $80 \%$ of exchange after three months (kept at $0-5^{\circ}$ ). The isomer $1-4,4-d_{2}$ exchanges only $8.5 \%$ of deuterions after one day. The detailed results for $\underline{1}-4,4-d_{2}$ and $\underline{1}-7,7-d_{2}$ exchanges are available on request from the authors.

\section{Results and discussion}

\subsection{The $\mathrm{Fe}(P A)_{2}$ oxidation}

The reaction of four alkaloids with $\mathrm{Fe}(\mathrm{PA})_{2}$ leads to product profiles as presented in Table 1 . The total organic conversion is low and the substrate recovery level is important (38-84\%), the hydroxylation of three alkaloids being a major reaction for $\underline{1}, \underline{3}$ and $\underline{4}$. The yields of these reactions are relatively small. The reduced ibogaine $\underline{2}$ is a major reaction product formed with $\mathrm{Fe}(\mathrm{PA})_{2}$. The lactamination of these alkaloids is in general as important as the reduction. For the reserpine ( $\underline{3})$ and the ajmaline (4), a relatively important dihydroxylation level is observed.

A third reaction characteristic for $\mathrm{Fe}(\mathrm{PA})_{2}$ oxidation, the pyridine coupling, was observed for all four alkaloids. The yield of these products is smaller than for the Gif reaction for the same series of substrates (Table 2) [13]. For compound 1 , the mono-hydroxycarboline, a major hydroxylation product, observed from the profile of $\mathrm{m} / \mathrm{z} 242$ ion, was identified as 6-hydroxycarboline. For the carboline (1), the same position was activated by all Gif catalysts previously studied by our group [19].

\subsection{The Cyt. P450 oxidation}

The insertion of the family of indolic bases into the Cyt. P450 was studied using six reaction conditions by two routes, the enzyme assisted NADPH and the radical hydroperoxide CumOOH route.

The results of oxidations of four indolic bases under PB, DEX and 3-MC induced P450 reactions showed consistently that the indolic substrates enter the Cyt. P450 active site. The Cyt. P450 cavity is ready to react with indolic derivatives and recognizes their planar or globular character (Tables 3A-D). This was confirmed by static interactions between Fe(III) P450 and the substrate leading to Type I 
Table 3A

Oxidation efficiencies of carboline $(1)^{\mathrm{a}}$

\begin{tabular}{|c|c|c|c|c|c|c|}
\hline \multirow[t]{2}{*}{ Conditions } & \multirow{2}{*}{$\begin{array}{l}\text { Total yield } \\
\text { of products } \\
\text { (\%) }\end{array}$} & \multicolumn{5}{|c|}{ Product profiles (\%) } \\
\hline & & $\begin{array}{l}\text { red }^{\mathrm{c}} \\
\mathrm{M}+2\end{array}$ & $\begin{array}{l}\text { one } \\
\mathrm{M}+14\end{array}$ & $\begin{array}{l}\text { ol } \\
\mathrm{M}+16\end{array}$ & $\begin{array}{l}\text { dione } \\
\mathrm{M}+28\end{array}$ & $\begin{array}{l}\text { diol } \\
\mathrm{M}+32\end{array}$ \\
\hline \multicolumn{7}{|l|}{$\overline{\mathrm{NADPH}}$} \\
\hline$\overline{\mathrm{PB}}$ & 5.8 & 26 & 13 & 46 & 8 & 6 \\
\hline DEX & 3.1 & 23 & 22 & 28 & 12 & 14 \\
\hline 3-MC & 4.9 & 22 & 12 & 46 & 8 & 11 \\
\hline \multicolumn{7}{|l|}{ CumOOH } \\
\hline$\overline{\mathrm{PB}}$ & 6.9 & 27 & 18 & 24 & 17 & 13 \\
\hline DEX & 3.2 & 26 & 26 & 26 & 10 & 10 \\
\hline 3-MC & 4.6 & 26 & 21 & 28 & 10 & 14 \\
\hline
\end{tabular}

Abbreviations used: red (reduction product, $\mathrm{M}+2$ ion), one (keto product, $\mathrm{M}+14$ ) ion, ol (hydroxy product, $\mathrm{M}+16$ ion), dione (diketo product, $\mathrm{M}+28$ ), diol (dihydroxy product, $\mathrm{M}+32$ ion).

a Average of two independent reactions, in these series $74-84 \%$ of 1 were isolated.

b $20 \mu \mathrm{g}$ of substrate/incubation, total of substrate + five products ion current over TIC, (\%).

${ }^{\mathrm{c}} \mathrm{M}+2$ can result of either a reduction reaction or of a demethylation + oxydation reaction.

Table 3B

Oxidation efficiencies of ibogaine (2) ${ }^{\mathrm{a}}$

\begin{tabular}{|c|c|c|c|c|c|c|}
\hline \multirow[t]{2}{*}{ Conditions } & \multirow{2}{*}{$\begin{array}{l}\text { Total yield } \\
\text { of products } \\
(\%)\end{array}$} & \multicolumn{5}{|c|}{ Product profiles (\%) } \\
\hline & & $\begin{array}{l}\mathrm{red}^{\mathrm{c}} \\
\mathrm{M}+2\end{array}$ & $\begin{array}{l}\text { one } \\
\mathrm{M}+14\end{array}$ & $\begin{array}{l}\text { ol } \\
\mathrm{M}+16\end{array}$ & $\begin{array}{l}\text { dione } \\
\mathrm{M}+28\end{array}$ & $\begin{array}{l}\text { diol } \\
M+32\end{array}$ \\
\hline \multicolumn{7}{|l|}{ NADPH } \\
\hline PB & 0.75 & 17 & 5 & 70 & 25 & 55 \\
\hline DEX & 0.8 & 6 & 33 & 12 & 14 & 36 \\
\hline $3-\mathrm{MC}$ & 6.5 & 9 & 6 & 72 & 4 & 9 \\
\hline \multicolumn{7}{|l|}{$\overline{\mathrm{CumOOH}}$} \\
\hline PB & 1.8 & 16 & 24 & 14 & 16 & 30 \\
\hline DEX & 1.9 & 16 & 29 & 19 & 15 & 21 \\
\hline 3-MC & 0.9 & 14 & 27 & 13 & 11 & 34 \\
\hline
\end{tabular}

Abbreviations used: red (reduction product, $\mathrm{M}+2$ ion), one (keto product, $\mathrm{M}+14)$ ion, ol (hydroxy product, $\mathrm{M}+16$ ion), dione (diketo product, $\mathrm{M}+28$ ), diol (dihydroxy product, $\mathrm{M}+32$ ion).

${ }^{a}$ Average of two independent reactions, in these series $48-79 \%$ of $\underline{2}$ were isolated.

b $20 \mu \mathrm{g}$ of substrate/incubation, total of substrate + five products ion current over TIC, (\%).

${ }^{c}$ See Table 3A.

interaction by the substrate binding into the P450 active site and an important modification of the iron environment.

The transformation of these substrates into products does not exceed 7\%. Five types of products were observed: reduced product (characterized by $\mathrm{M}+2$ ions) ${ }^{1}$, monoketo $(\mathrm{M}+14$ ion), monohydroxy product $(\mathrm{M}+16$ ion), diketo product $(\mathrm{M}+28 \mathrm{ion})$ and a diol, the last product resulting from an epoxide opening rather than dioxidation.

The oxidation of $\beta$-carboline (1) (Table 3A), via the NADPH route led mainly to monohydroxylated product during the $\mathrm{PB}$ and $3-\mathrm{MC}$ microsome reaction $(\approx 50 \%)$ with a total of $3-7 \%$ of organic material

\footnotetext{
${ }^{1}$ Some alkaloids with $\mathrm{N}-\mathrm{CH}_{3}$ or $\mathrm{O}-\mathrm{CH}_{3}$ groups can undergo demethylation under Cyt. $\mathrm{P} 450$ conditions. These products, after monohydroxylation, have two more mass units than the starting material. Because of the observed reduction of $\underline{1}$ and the low yields of all reactions, we are suggesting that reduction takes place rather than demethylation.
} 
Table 3C

Oxidation efficiencies of reserpine $(\underline{3})^{\mathrm{a}}$

\begin{tabular}{|c|c|c|c|c|c|c|}
\hline \multirow[t]{2}{*}{ Conditions } & \multirow{2}{*}{$\begin{array}{l}\text { Total yield } \\
\text { of products } \\
(\%) \\
\end{array}$} & \multicolumn{5}{|c|}{ Product profiles (\%) } \\
\hline & & $\begin{array}{l}\mathrm{red}^{\mathrm{c}} \\
\mathrm{M}+2\end{array}$ & $\begin{array}{l}\text { one } \\
\mathrm{M}+14\end{array}$ & $\begin{array}{l}\text { ol } \\
\mathrm{M}+16\end{array}$ & $\begin{array}{l}\text { dione } \\
\mathrm{M}+28\end{array}$ & $\begin{array}{l}\text { diol } \\
\mathrm{M}+32\end{array}$ \\
\hline \multicolumn{7}{|l|}{ NADPH } \\
\hline PB & 0.07 & 46 & 15 & 19 & 13 & 5 \\
\hline DEX & 0.04 & 9 & 2 & 79 & 6 & 35 \\
\hline 3-MC & 0.17 & 36 & 59 & 44 & 5 & 9 \\
\hline \multicolumn{7}{|l|}{ CumOOH } \\
\hline PB & 0.11 & 22 & 14 & 31 & 14 & 17 \\
\hline DEX & 0.15 & 22 & 8 & 31 & 6 & 38 \\
\hline 3-MC & 0.03 & 47 & 4 & 27 & 17 & 4 \\
\hline
\end{tabular}

Abbreviations used: red (reduction product, $\mathrm{M}+2$ ion), one (keto product, $\mathrm{M}+14$ ) ion, ol (hydroxy product, $\mathrm{M}+16$ ion), dione (diketo product, $\mathrm{M}+28$ ), diol (dihydroxy product, $\mathrm{M}+32$ ion).

${ }^{a}$ Average of two independent reactions, in these series $38-74 \%$ of $\underline{3}$ were isolated.

b $20 \mu \mathrm{g}$ of substrate/incubation, total of substrate + five products ion current over TIC, (\%).

${ }^{c}$ See Table 3A.

Table 3D

Oxidation efficiencies of ajmaline $(\underline{4})^{\mathrm{a}}$

\begin{tabular}{|c|c|c|c|c|c|c|}
\hline \multirow[t]{2}{*}{$\overline{\text { Conditions }}$} & \multirow{2}{*}{$\begin{array}{l}\text { Total yield } \\
\text { of products } \\
(\%)\end{array}$} & \multicolumn{5}{|c|}{ Product profiles (\%) } \\
\hline & & $\begin{array}{l}\text { red }^{\mathrm{c}} \\
\mathrm{M}+2\end{array}$ & $\begin{array}{l}\text { one } \\
\mathrm{M}+14\end{array}$ & $\begin{array}{l}\text { ol } \\
M+16\end{array}$ & $\begin{array}{l}\text { dione } \\
\mathrm{M}+28\end{array}$ & $\begin{array}{l}\text { diol } \\
\mathrm{M}+32\end{array}$ \\
\hline \multicolumn{7}{|l|}{ NADPH } \\
\hline$\overline{\mathrm{PB}}$ & 3.0 & 16 & 20 & 45 & 15 & 4 \\
\hline DEX & 1.6 & 9 & 18 & 58 & 10 & 4 \\
\hline 3-MC & 5.6 & 19 & 14 & 43 & 18 & 5 \\
\hline \multicolumn{7}{|l|}{ CumOOH } \\
\hline$\overline{\mathrm{PB}}$ & 2.4 & 14 & 19 & 47 & 14 & 6 \\
\hline DEX & 2.4 & 12 & 15 & 49 & 19 & 4 \\
\hline 3-MC & 2.5 & 9 & 16 & 52 & 13 & 3 \\
\hline
\end{tabular}

Abbreviations used: red (reduction product, $\mathrm{M}+2$ ion), one (keto product, $\mathrm{M}+14$ ) ion,

ol (hydroxy product, $\mathrm{M}+16$ ion), dione (diketo product, $\mathrm{M}+28$ ), diol (dihydroxy product, $\mathrm{M}+32$ ion).

${ }^{a}$ Average of two independent reactions, in these series $53-84 \%$ of 4 were isolated.

b $20 \mu \mathrm{g}$ of substrate/incubation, total of substrate + five products ion current over TIC, (\%).

${ }^{\mathrm{c}}$ See Table 3A.
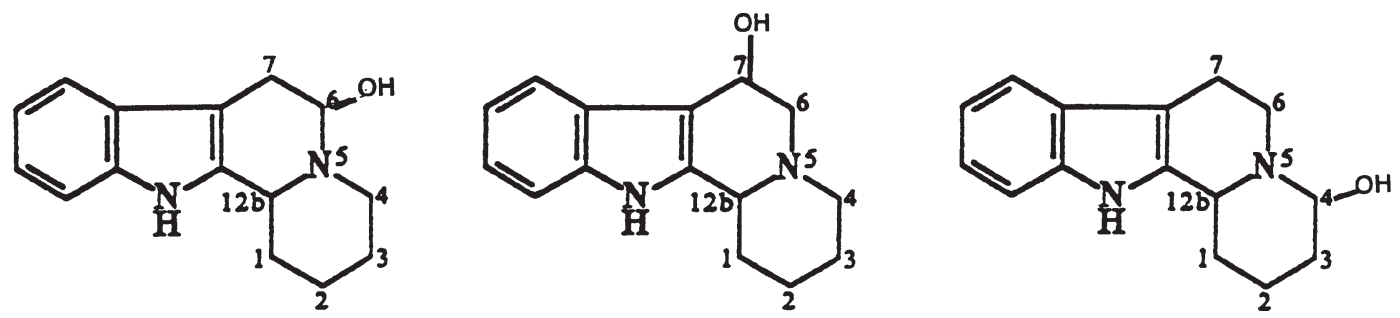

Fig. 2. Monohydroxylation of $\underline{1}$.

conversion and approximately $80 \%$ of starting material recovered. However, the DEX NADPH and the three peroxide route oxidations did not produce such a specificity (Fig. 2).

The position of hydroxylation was identified by comparison with oxidation of dideuterated carboline 

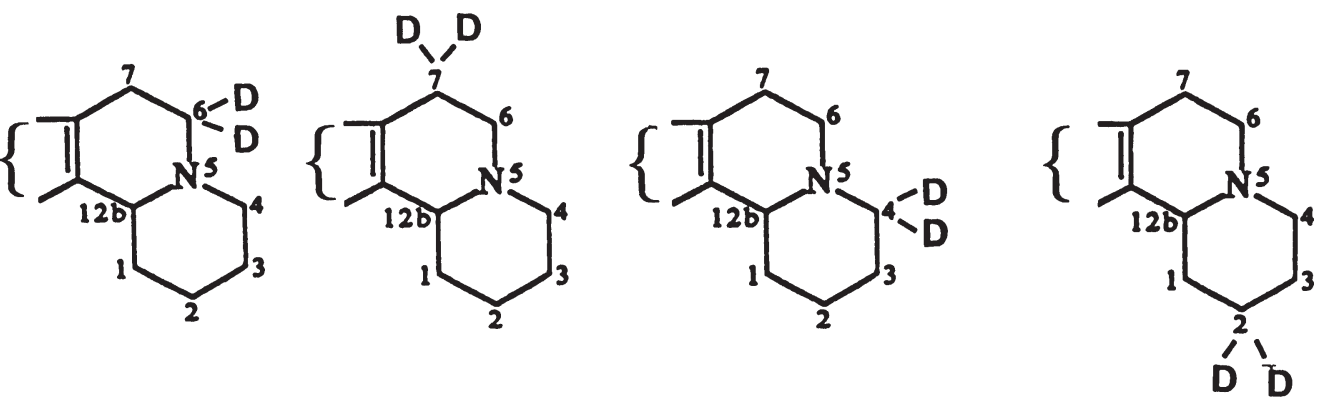

Fig. 3. Deuterated carboline.

(e.g., 4,4- $d_{2}, 6,6-d_{2}, 7,7-d_{2}$, etc.) models available. The profile of the $\mathrm{m} / \mathrm{z} 242$ signal corresponding to hydroxycarboline mass displays three possible hydroxy carbolines which were identified as 6hydroxy, 4-hydroxy and 7-hydroxy respectively, Table 2. The comparison of ion chromatogram profiles of hydroxy monodeuterated $(\mathrm{m} / \mathrm{z} 243)$ or dideuterated $(\mathrm{m} / \mathrm{z} 244)$ carbolines led to unambiguous identification of 6-hydroxycarboline as a major hydroxylation product from substitute 1 (Fig. 3).

The oxidation of these three methylenes, instead of the less hindered methylenes at $\mathrm{C}_{2}$ or $\mathrm{C}_{3}$, suggests that the $\mathrm{C}_{7}, \mathrm{C}_{6}$ and $\mathrm{C}_{4}$ methylenes are almost in a linear arrangement (Fig. 4). Based on a model of the substrate $\underline{1}$, its approach to the active site of the P450 and the assumed similarity between microorganism and mammal P450, the substrate should be retained over the heme oxidation site. Thus the three methylenes cross the p orbital of the oxygen iron link, perpendicular to the heme surface (Fig. 5). The carboline first engages its aliphatic part, rings $\mathrm{C}-\mathrm{D}$, via a channel leading into the heme. The formation of $\mathrm{Fe}(\mathrm{V})=\mathrm{O}$ (or $\mathrm{Fe}(\mathrm{III})-\mathrm{O}-\mathrm{O}^{-}$) complex prior to the oxidation is usually proposed. From the possible orientations of $\mathrm{H}-12 \mathrm{~b} \beta \underline{1}$, in three conformations toward the Val 295, Phe 87 and the heme Fe reference points, the sliding of the aromatic part from the anti to Val 295 side, opposite to the Fe-Cys 357, better explains the alignment of these three methylenes and their propensity to oxydation. Otherwise the aromatic part is hindered by the beta sheets $\left(\beta_{3}\right)$ and helix I, both part of the Cyt. P450. The amino acids from $\beta_{3}$, Val 295 and Leu 244 as well as helix I are playing this role in particular. Although the identification of hydroxylation position as $\alpha$ or $\beta$ on the carboline skeleton was not possible, we suppose that all indolic bases are hydroxylated on the same site, e.g., syn to $\mathrm{H}-12 \mathrm{~b}$, as in conformation where the aliphatic part of the carboline points to the heme site. This arrangement is consistent with the Poulos cysteine pocket structure [36-39] as well as with the Cyt. P450 steroids oxidation sites (Fig. 5) [1-3,40,41].

In all reactions involving $\beta$-carboline, an appreciable amount of the reduced carboline was observed. The reduction is often present under the reactive conditions enabling, e.g., $\bullet \mathrm{CCl}_{3}$ formation from $\mathrm{CCl}_{4}$, from other easily reduced substrates or Cyt. P450 reductases.

The oxidation of the ibogaine $\underline{2}$ led to the observations summarized in Table 3B. Compared with carboline the reaction yields, the substrate recovery level was much lower. The NADPH route of oxidation showed a predominant $(70 \%)$ product mixture of hydroxy ibogaine for the PB and 3-MC treated rat microsomes. The DEX P450 mediated route displayed almost $70 \%$ of the combined onediol couple which is consistent with the double oxidation trend displayed by this molecule. The peroxide route followed the same direction, however, there was no distinguishable major oxidation product in this reaction. The identification of the hydroxylation position of the two reaction products will be attempted as soon as a larger quantity of hydroxy ibogaine becomes available from the 3-MC initiated reaction mixture. 


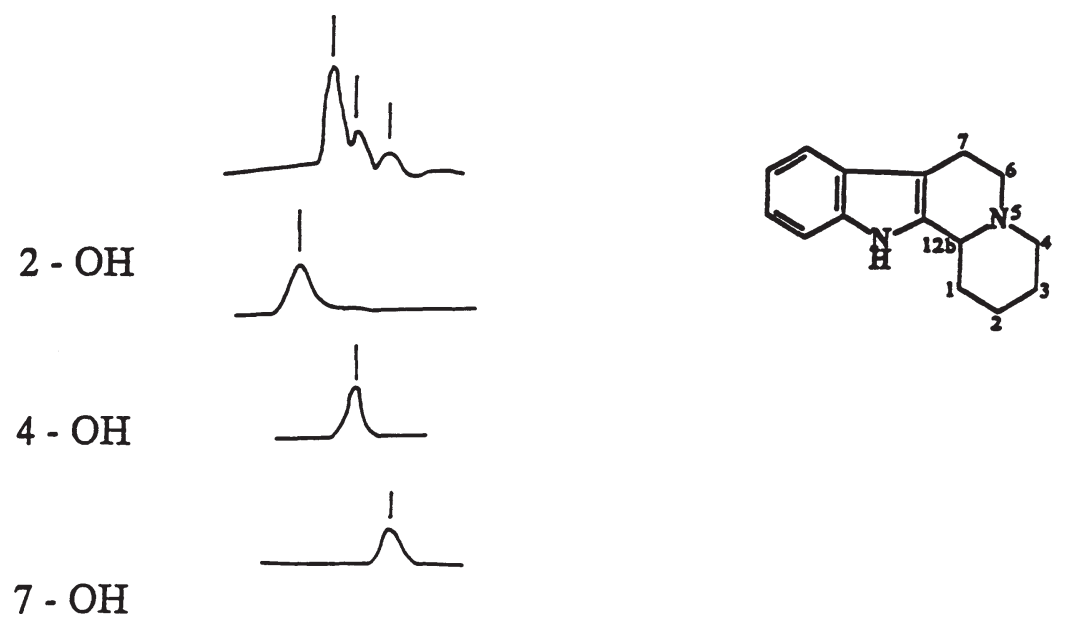

(a)

\begin{tabular}{|c|c|cc|cc|cc|c|}
\hline \multicolumn{10}{|c|}{$\mathrm{m} / \mathrm{z}$} \\
$\mathrm{M} 6-\mathrm{OH}$ & + & + & - & - & + & - & + & + \\
$\mathrm{M} 4-\mathrm{OH}$ & + & - & + & - & + & + & - & + \\
$\mathrm{M} 7-\mathrm{OH}$ & + & - & + & + & - & - & + & + \\
& & & & & & & & \\
& & & & & & & \\
& $-\mathrm{d}_{\mathrm{o}}$ & $6,6-\mathrm{d}_{2}$ & $7,7-\mathrm{d}_{2}$ & $4,4-\mathrm{d}_{2}$ & $24,2-\mathrm{d}_{2}$ \\
\hline
\end{tabular}

(b)

Fig. 4. (a) Identification of 6-hydroxy carboline m/z 242 ion mass chromatogram profile (2-hydroxy, 4-hydroxy and 7-hydroxy carboline model compounds shown). (b) Identification of 6-hydroxy carboline. Comparison of 242, 243 and 244 ion mass chromatograms (signs + or - denote presence or absence or these ions respectively).

The next alkaloid studied, reserpine (3), presented the worst metabolite yields in these series, probably due to its solubility under different Cyt. P450 conditions (Table 3C). In the NADPH route, however, a specific hydroxylation of $\underline{3}$ was observed via the DEX induced P450 initiated reaction. The profile of the peroxide route product did not differ much from the other alkaloids. In the reserpine reaction, a relatively high amount of reduced reserpine was observed but a tentative identification of hydroxy reserpine will be attempted for the NADPH DEX route only. The absence of more vigorous reactions with Cyt. P450 could be related to the presence of trimethoxyphenyl moiety which can successfully compete for the binding place on the heme site with the equally planar indolic part of this alkaloid. This radical becomes a major hindrance factor in the proximity of the heme cavity.

The oxidation of the last alkaloid, ajmaline (4) (Table 3D), displayed average metabolite yields of circa 3\% and a relatively large amount of hydroxylated ajmaline accounting for approximately half of the extracted product, across the board regardless of the reaction conditions applied. These results show that the ajmaline is not specifically recognized because of its shape which is less planar but not enough globular. Also the two hydroxy groups of $\underline{4}$ already present in this molecule could interfere 


\section{$B_{3}$}

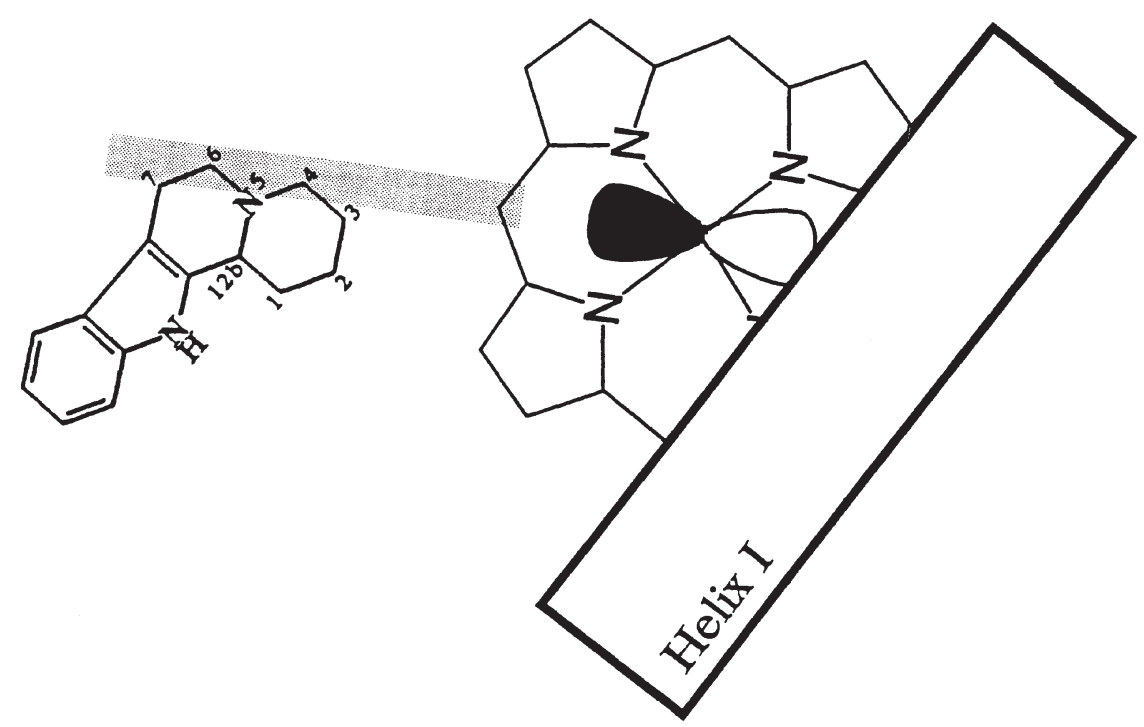

Fig. 5. Hypothesis of oxidation of methylenes 4, 6 and 7 of the carboline 1 on the Cyt. P450 active site. Three methylenes are oriented in line toward the $\mathrm{Fe}-\mathrm{O}$ of the heme, the substrate is moving from the right to the left of the figure.

with formation of both, P450-substrate or active site-substrate, complexes [42,43].

The identification of hydroxylation position for substrates $\underline{2}-\underline{4}$ was not possible because of the lack of specifically labelled or deuterated derivatives combined to a low yield of metabolites.

\section{Conclusion}

Two oxidations performed on the indolic bases, with $\mathrm{Fe}(\mathrm{PA})_{2}$ as well as under various Cyt. $\mathrm{P} 450$ conditions lead exclusively to the alicyclic hydroxylation products. The absence of aromatic hydroxylation was confirmed by the mass spectroscopic data and by comparison with model compounds.

The soft oxidation of alkaloids with $\mathrm{Fe}(\mathrm{PA})_{2}$ yields only a small amount of products accompanied by the usual pyridine coupling products. Practically, the use of this reaction to obtain hydroxy or keto indolic alkaloids remains limited. However, a specific recognition of these substrates as well as their metabolism by the Cyt. P450 active site was observed in oxidations with Cyt. P450. It seems possible that the alkaloids $\underline{1}-\underline{4}$ do not act as xenobiotic inhibitors of Cyt. P450 [42,43].

The alkaloids are metabolized more specifically via the reduced NADPH route than via the CumOOH route. This way offers two electrons, one by one, in order to form the active $\mathrm{Fe}(\mathrm{V})=\mathrm{O}$ while in the $\mathrm{CumOOH}$ route the direct formation of $\mathrm{Fe}(\mathrm{V})=\mathrm{O}$ occurs. Carboline 1 is recognized and hydroxylation under $\mathrm{PB}$ and 3-MC initiated conditions is observed with relatively reasonable yields. In general, under three initiations via the $\mathrm{CumOOH}$ way, the specificity is lacking from the oxidation. In all of these reactions, the reduced products were also observed. 
The identification of the three monohydroxy carbolines using deuterated alkaloids stimulated further studies and eventual modelisation [44-46].

The easiest and the most difficult to oxidize of the four alkaloids are the carboline 1 and reserpine $\underline{3}$, respectively. The yield of oxidation products still remains low in the Cyt. P450 series.

The comparison of oxidation reactions of indolic bases (Table 2) clearly indicates higher reaction yields observed for Gif and $\mathrm{Fe}(\mathrm{PA})_{2}$ reagents than with the Cyt. P450 under six different oxidation conditions.

Judging from the obtainment of reduced as well as oxidized (keto/diol) sequence products, the pyrrolic double bond of indolic alkaloids is activated under Cyt. P450 conditions.

The comparison of the three oxidations ( $\mathrm{Gif}, \mathrm{Fe}(\mathrm{PA})_{2}$ and Cyt. P450) leads to the hypothesis of a similar planar site structure for the trinuclear catalyst, picolinate and heme which is necessary to achieve an oxidation. In all cases, the formation of an oxidized Fe-substrate bond with the participation of $\mathrm{N}_{5}$ on the junction of the $\mathrm{C}$ and $\mathrm{D}$ rings, led to the activation of relatively unhindered neighbour methylenes. All three reactions are then related and judging by our results, the Gif-Cyt. P450 analogies are, despite the opposite claims, striking [47-49].

\section{Acknowledgements}

We would like to thank C. Bernard and DeWei Lu (UdeM) who have participated in the preliminary phase of this work. The help of the Faculty of Research and Graduate Studies (UdeM), N.B. Health Department and CEN de Saclay is gratefully acknowledged.

\section{References}

[1] P.R. Ortiz de Montellano, Cytochrome P450: Structure, Mechanism and Biochemistry, Plenum Press, New York, 1986, 77.

[2] W.B. Jacoby, Enzymatic Basis of Detoxication, Acad. Press, Orlando, 1980.

[3] R.E. White and M.J. Coon, Ann. Rev. Biochem. 49 (1980), 315.

[4] D.H.R. Barton, Aldrichimica Acta 23(1) (1990), 3 (review).

[5] D.H.R. Barton and D. Doller, Acc. Chem. Res. 25 (1992), 504.

[6] M.R. Waterman and E.F. Johnson, Cytochrome P450. Methods in Enzymology 206, Acad. Press, 1991.

[7] D.H.R. Barton, M.J. Gastiger and W.B. Motherwell, J. Chem. Soc., Chem. Commun., 1983, 41-43.

[8] G. Balavoine, D.H.R. Barton, J. Boivin, P. Lecoupanec and P. Lelandais, New J. Chem. 13 (1989), 691-700.

[9] D.H.R. Barton, F. Halley, N. Ozbalik, M. Schmitt, E. Young and G. Balavoine, J. Am. Chem. Soc. 111 (1989), 7144-7149.

[10] G. Balavoine, D.H.R. Barton, J. Boivin, A. Gref, N. Ozbalik and H. Rivière, Tetrahedron Lett. 27 (1986), $2849-2852$.

[11] D.H.R. Barton, F. Halley, N. Ozbalik, E. Young, G. Balavoine, A. Gref and J. Boivin, New J. Chem. 13 (1989), $177-182$.

[12] C. Sheu, A. Sobkowiak, L. Zhang, N. Ozbalik, D.H.R. Barton and D.T. Sawyer, J. Am. Chem. Soc. 111 (1989), 8030.

[13] F.A. Fares and K. Jankowski, Heterocycles 34(11) (1992), 2113.

[14] D.H.R. Barton, E. Csuhai and N. Ozbalik, Tetrahedron Lett. 31 (1990), 2817-2820.

[15] E. About-Jaudet, D.H.R. Barton, E. Csuhai and N. Ozbalik, Tetrahedron Lett. 31 (1990), 1657-1660.

[16] S. Kominami, A. Higuchi and S. Takemori, Bioch. Bioph. Acta 937 (1988), 177.

[17] M.A. Peyronneau, M. Delaforge, R. Rivière and D. Mansuy, Eur. J. Biochem. 223 (1994), 947-956.

[18] K. Jankowski and D.W. Lu, Spectroscopy 11 (1993), 59.

[19] K. Jankowski, E. Godin and N. Cundasawmy, Can. J. Chem. 52 (1974), 2064.

[20] G.W. Gribble, Procedures J. Org. Chem. 11 (1972), 1833.

[21] G.W. Gribble and R.B. Nelson, J. Org. Chem. 39 (1974), 1845.

[22] C. Sheu, S.A. Richert, P. Cofré, B. Ross, Jr., A. Sobkowiak, D.T. Sawyer and J.R. Kanofksy, J. Am. Chem. Soc. 112, (1990), 1936. 
[23] C. Sheu, A. Sobkowiak, S. Jeon and D.T. Sawyer, J. Am. Chem. Soc. 112 (1990), 879.

[24] P. Cofré, S.A. Richert, A. Sobkowiak and D.T. Sawyer, Inorg. Chem. 29 (1990), 2645.

[25] H.-Ch. Tung and D.T. Sawyer, J. Am. Chem. Soc. 112 (1990), 8214.

[26] P. Kremers, P. Beaune, T. Cresteil, S. Degrave, S. Columelli, J.P. Leroux and J. Gielen, Eur. J. Biochem. 118 (1981), 599.

[27] O.H. Lowry, N.J. Rosebrough, A.L. Farr and R.J. Randall, J. Biol. Chem. 193 (1951), 265-275.

[28] T. Omura and R. Sato, J. Biol. Chem. 239 (1964), 2370-2379.

[29] K. Jankowski, M.W. Poirier and F.A. Farès, Spectroscopy 10 (1992), 105.

[30] H.H. Mauer, Arch. Toxicol. 64 (1990), 218.

[31] V. Ullrich, Angew. Chem. Int. Edit. 11 (1972), 7-7.

[32] V. Ullich, Z. Physiol. Chem. 350 (1969), 357.

[33] D.H.R. Barton, J. Boivin, W.B. Motherwell, N. Ozbalik, K. Schwartzentruber and K. Jankowski, Nouv. J. Chim. 10 (1986), 387.

[34] D.H.R. Barton, A.K. Gokturk and K. Jankowski, J. Chem. Soc., Perkin Trans. 1 (1985), 2109.

[35] D.H.R. Barton, J. Boivin, J.C. Beloeil, A. Billion, J.Y. Lallemand, P. Lelandais, S. Mergui, N. Morellet and K. Jankowski, Nouv. J. Chim. 10 (1986), 440.

[36] T.L. Poulos, B.C. Finzel and A.J. Howard, J. Mol. Biol. 195 (1987), 687.

[37] T.L. Poulos, B.C. Finzel, I.C. Gunsalus, G.C. Wagner and J. Kraut, J. Biol. Chem. 260 (1985), 16122.

[38] T.L. Poulos, M. Perez and G.C. Wagner, J. Biol. Chem. 257 (1982), 10427.

[39] T.L. Poulos, B.C. Finzel and A.J. Howard, Biochemistry 25 (1986), 5314.

[40] D. Mansuy, Europ. J. Bioch. 184 (1989), 267.

[41] R.B. Silverman, The Org. Chem. of Drug Design and Drug Actions, Acad. Press, N.Y., 1991, Chapters 4 and 7 , pp. 136, 238.

[42] K. Bachmann, G. Sanyal, J. Potter, R. Schiavone and J. Loch, Pharmacology 47 (1993), 1.

[43] C. Koeppel, J. Tenczer and I. Arndt, Eur. J. Drug Metab. Pharmacokinet. 14 (1989), 309.

[44] P.J. Plourde, N.K. Srivastava, F. Soler, M. Delaforge, N. Turkkan and K. Jankowski, ACFAS 71 (1993).

[45] P.J. Plourde, N.K. Srivastava, F. Soler, M. Delaforge, N. Turkkan and K. Jankowski, ACFAS 75 (1994).

[46] P.J. Plourde and K. Jankowski, J. Mol. Structure (in preparation, 1996).

[47] D.H.R. Barton, E. Csuhai, D. Doller, N. Ozbalik and G. Balavoine, Proc. Natl. Acad. Sci. USA 87 (1990), 3401.

[48] J. Green and H. Dalton, J. Biol. Chem. 263 (1988), 17561.

[49] A. Ericson, B. Hedman, K.O. Hodgson, J. Green, H. Dalton, J.G. Bentsen, R.H. Beer and S.J. Lippard, J. Am. Chem. Soc. 110 (1988), 2330. 


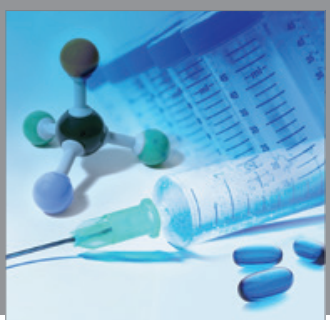

International Journal of

Medicinal Chemistry

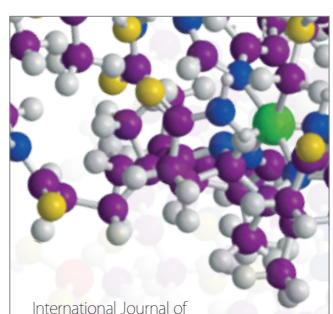

Carbohydrate Chemistry

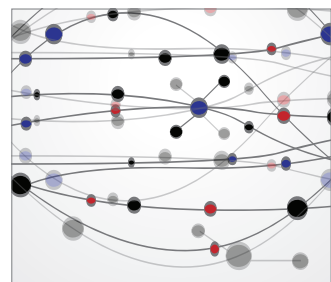

The Scientific World Journal
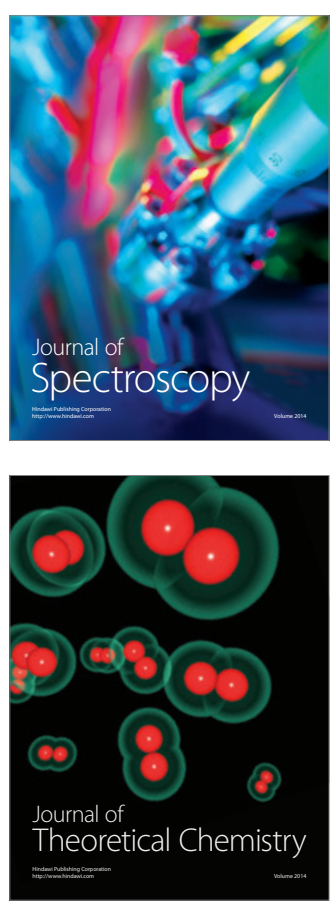
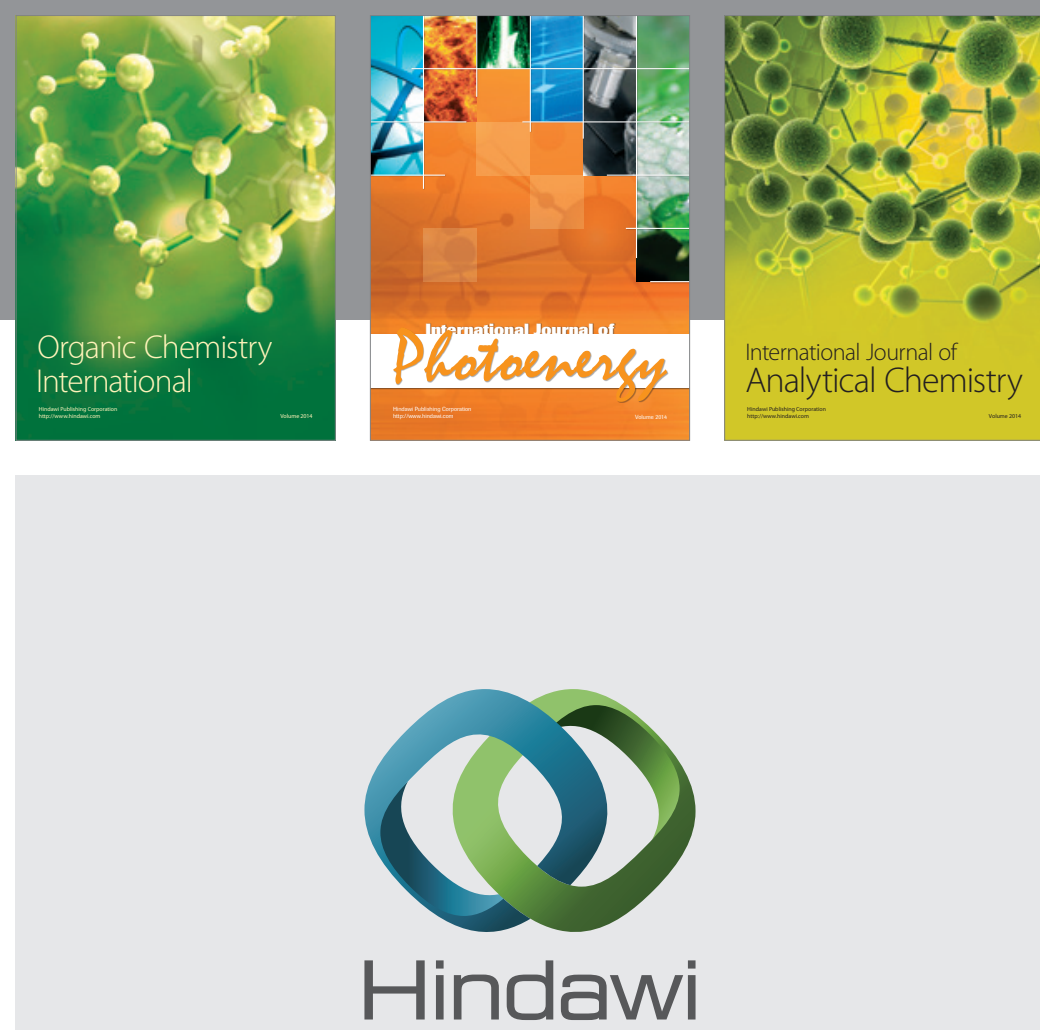

Submit your manuscripts at

http://www.hindawi.com
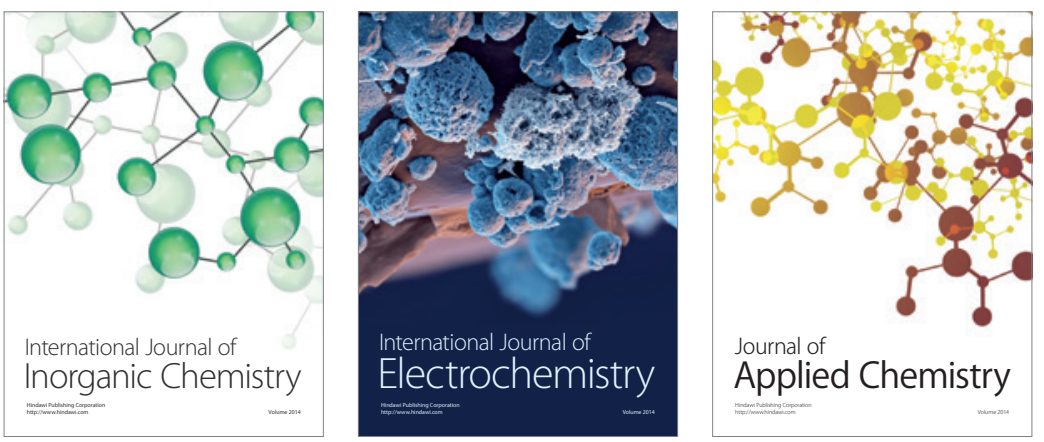

Journal of

Applied Chemistry
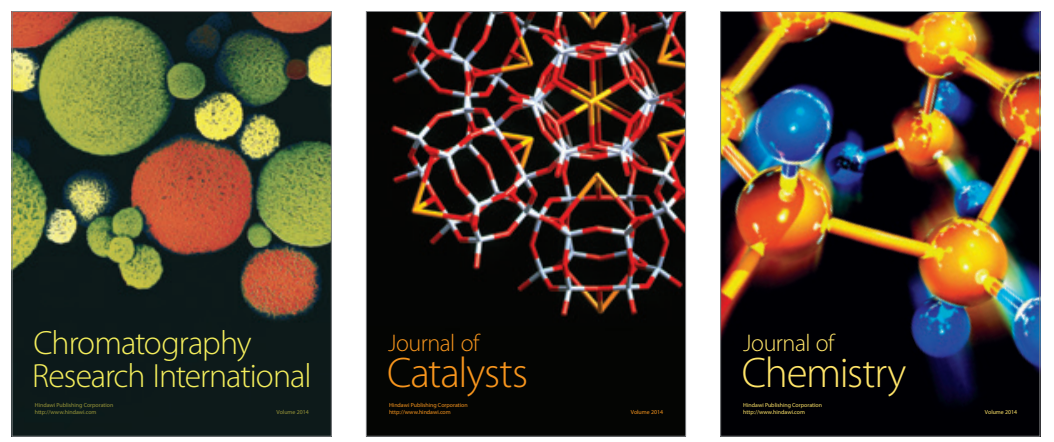
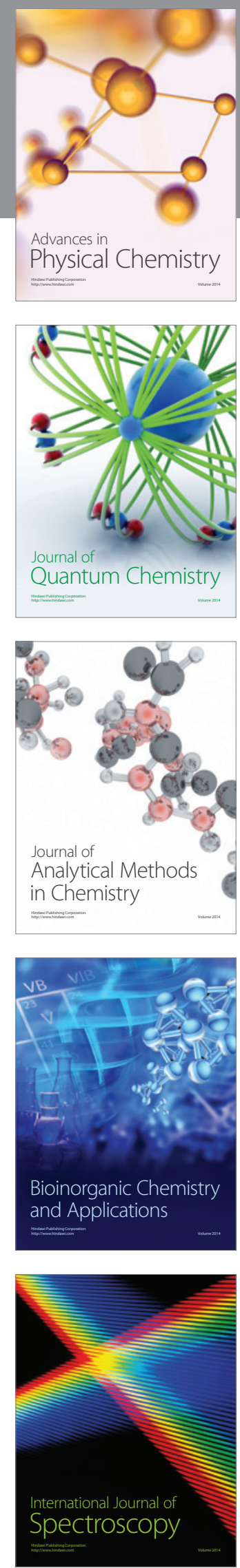